\title{
IMPLEMENTATION OF DUAL HEALTH ASSET APPLICATIONS DEVELOPED BY MINISTRY OF INTERNAL AFFAIRS AND MINISTRY OF HEALTH IN HOSPITALS IN BOYOLALI, CENTRAL JAVA
}

\author{
Yunita Rusdiyanti'1), Didik Gunawan Tamtomo²), Bhisma Murti ${ }^{1)}$ \\ 1) Masters Program in Public Health, Universitas Sebelas Maret \\ 2)Faculty of Medicine, Universitas Sebelas Maret
}

\begin{abstract}
Background: Information systems management and facility (SIMDA-BMD) and equipments maintenance management application (ASPAK) is a technology that was developed to support the achievement of health care. The study indicated that SIMDABMD and ASPAK in operationally and economically provide significant impact on the fund effectiveness, efficiency and time efficiency. The purpose of this study was to investigate the implementation of SIMDA-BMD and ASPAK.

Subjects and Method: This was a descriptive qualitative study with case study approach. The study was conducted at 3 hospitals in Boyolali, Central Java. The key informants were treasurer of goods, treasurer of goods storage, head of planning and reporting, head of ASPAK, head of medical support and head of application of facilities, infrastructure and medical devices administration. The informants selected by purposive sampling. The data were analyzed by in-depth interview, participative observation, and document observation. The data were analyzed by data reduction, data presentation, and drawing conclusion.

Results: The implementation of health assets at the Regional General Hospital in Boyolali Regency has a difference in the grouping of the final results with the SIMDABMD based on the inventory card and the total asset value and ASPAK, based on the percentage of efforts to fulfill the standards according to the hospital class.

Conclusion: The implementation of the SIMDA-BMD and ASPEK asset applications complement each other so that quality management is needed to reduce referral number.
\end{abstract}

Keywords: asset implementation, information systems management and facility, equipments maintenance management application

\section{Correspondence:}

Yunita Rusdiyanti. Masters Program in Public Health, Universitas Sebelas Maret. Jl. Ir. Sutami 36A, Surakarta 57126, Central Java. Email: y_rusdiyanti@yahoo.com. Mobile: 08122981365. 